\title{
No Questions Asked? Development and the Paradox of China's Africa Policy
}

FODEI BATTY*

ABSTRACT This paper argues that China's strategy of engaging African countries through its stated "no questions asked" foreign policy could ultimately be counter-productive for Chinese interests on the continent. Whereas the policy allows China to engage Africa's authoritarian dictators and democrats alike as it invests in energy, infrastructure, mining, and other projects without many restraints or preconditions; opposition groups across the continent have seized upon its presumed support for unpopular incumbent regimes to stir opposition to China among Africa's masses during recent elections. Unless China's policymakers modify their Africa policy, China's investments in Africa are ironically producing the conditions of development, such as the proliferation of cheap cellphone technology and an expanding African middle class, alongside increasingly dissenting voices over their strategy and presence in Africa.

\section{Introduction}

s China preying on Africa's resources and undermining development and democracy on the continent by supporting authoritarian regimes, as several scholars and analysts have claimed ${ }^{1}$ This paper takes a contrary viewpoint and argues that China's investments in Africa, now totaling well in excess of $\$ 100$ billion and growing, ${ }^{2}$ could be ultimately counterproductive for China's interests in Africa if the lessons of modernization theory hold, and if China continues to indiscriminately conduct business with Africa's authoritarian regimes under its "no questions asked" foreign policy. According to the postulates of modernization theory, economic growth creates an educated middle class that aspires for democracy and a free society. ${ }^{3}$ Thus, if Chinese investments are, in fact, producing jobs in Africa and helping foster economic growth on the continent, then Chinese policymakers should be most worried about several attendant effects of economic development over the longer term, such as its mutual relationship with democracy and freer societies. Although the projected relationships and expectations between economic development and democracy have, so far, failed to emerge within China itself, the nucleus

* Quinnipiac University, U.S. 2019, pp. 151-166 


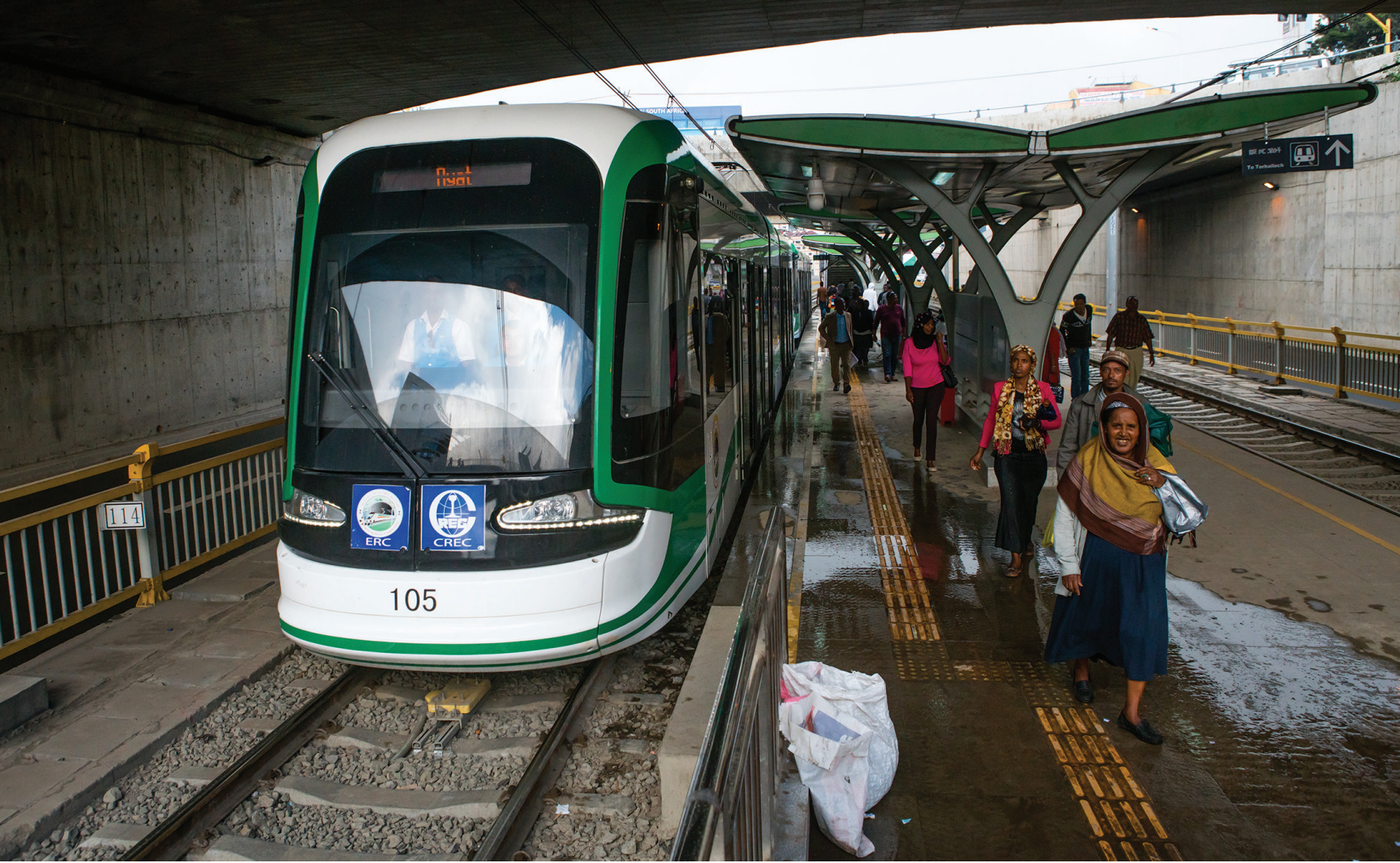

The first sub-

Saharan light

railway system,

which started

operating in

2015, was buit

in Addis Ababa,

Ethiopia with

Chinese funding

and expertise.

ERIC LAFFORGUE /

Corbis via Getty

Images

of such outcomes exists within many African societies, as this paper makes clear.

At the Forum on China-Africa Cooperation (FOCAC) summit held in Beijing, China on September 3-4, 2018, Chinese President Xi Jinping reiterated China's "five-no approach" foreign policy in its relations with Africa as: "(i) no interference in African countries' pursuit of development paths that fit their national conditions; (ii) no interference in African countries' internal affairs; (iii) no imposition of our will on African countries; (iv) no attachment of political strings to assistance to Africa; (v) and no seeking of selfish political gains in investment and financing cooperation with Africa." Going further, President $\mathrm{Xi}$ said: "We hope this "five-no" approach could apply to other countries as they deal with matters regarding Africa. For China, we are always Africa's good friend, good partner and good brother. No one could undermine the great unity between the Chinese people and the African people." ${ }^{5}$

Drawing from the evidence of recent electoral contestations and the political and popular discourse in Africa and among the African diaspora, I argue that Xi's stated principles of China's engagement with African countries are misguided and outdated because they are out of tandem with popular aspirations for the continent's future. However, China cannot export or address democracy because it is itself governed by an authoritarian regime that does not have any experience with democratic ideals and would not know how to translate 


\section{China's current Africa policy fails to recognize, or ignores the fact, that what Africans really want is a model of democratic governance that China is incapable of offering them}

such ideals to other societies, even if it wanted to. Furthermore, preaching democracy overseas would serve to delegitimize the Chinese Communist Party at home after it has maintained a stranglehold on political power in China since 1949. Ultimately, China's current Africa policy could also be counterproductive for China itself.

To be clear, I do not ignore or make assumptions about the reports of widespread corruption in Africa frequently cited as one of the main reasons for bad governance in African countries that drives African politicians to covet "easy money" from China. Rather, the point is that China's current Africa policy fails to recognize, or ignores the fact, that what Africans really want is a model of democratic governance that China is incapable of offering them. ${ }^{6}$

Unless there is a change in investment strategy or unless it is the case that Chinese infiltration and exploitation of the continent's resources is so debilitating as to make it virtually impossible for any gains to be realized, then China's sustained investments in African countries in pursuit of the interests described by President Xi should eventually produce the necessary conditions for economic development. Economic development could subsequently expand the sizes of the educated and aspirational African middle classes forming a critical mass with differing voices on China's contentious presence in their countries. In a virtuous cycle proposed by modernization theory, which is exemplified by the case of South Korea beginning in the 1960s under the Park regime, ${ }^{7}$ the middle classes are much more likely to prioritize political liberalization. This should increase the likelihood of advancing and deepening democratization that, subsequently, should help rid the continent of authoritarian governance and China's influence, if China continues its "no questions asked" policy that condones authoritarian governments in Africa.

As a caveat, the components of the argument for a reciprocal relationship between development and democracy that could lead to increased dissent over China in Africa are hard to unpack because development is fungible and hard to disaggregate in aid-recipient countries. It is difficult, for example, to distinguish between what intervention, Chinese or Western aid, is responsible for producing a specific outcome, such as increased civil society activism in a country and who should take credit for such increase. ${ }^{8}$ It is also difficult to pinpoint exact time points for the emergence of specific outcomes, such as an educated 
If the claim that China is a new neo-colonial power pervades the continent, it could be expected that a series of "anti-China protests" will erupt in cities and towns across Africa and aspirational middle class. For example, it took South Korea eight years to become a democracy after it became an industrial economy. ${ }^{9}$ What is clear, however, is that the overall expected outcomes, such as increased political competence and efficacy of citizenries, which come with the kind of investments China is making in various sectors of African countries are highly probable owing to the consistent finding of a reciprocal relationship between development and democracy.

\section{From North-South to South-South Exploitation?}

Indeed, we are already seeing some of the counter-effects of China's investment activities in motion in countries such as Sierra Leone where China became a major election issue in 2018 at the expense of the incumbent All People's Congress Party (APC). As that country headed into closely contested presidential and parliamentary elections on March 7, 2018, several issues regarding the economy, corruption, endemic poverty, the embezzlement of donor funds intended for the Ebola epidemic and the mudslide disaster of 2017, and the citizenship of presidential aspirants and candidates for parliament dominated the campaigns for votes. In addition, two videos involving the Chinese presence in the country appeared on social media and went viral on WhatsApp, Facebook, and other platforms frequented by Sierra Leoneans at home and in the diaspora in the days before the country voted. The videos generated streams of conversations and were widely credited by analysts for turning the electoral tide against the unpopular but resilient APC government.

In one of the videos and several accompanying still photographs, an APC parliamentary candidate is flanked by two Chinese nationals dressed in APC shirts and colors as the candidate and his entourage meet and canvass voters at a campaign event. ${ }^{10}$ The impression was that the candidate of the incumbent APC Party had the backing or endorsement of the Chinese. ${ }^{11}$ The Chinese embassy in Freetown was later compelled to issue a strenuous denial of interfering in the Sierra Leone elections nevertheless the damage was done. In the second video, Sylvanus Koroma, a brother of the incumbent APC president Ernest Koroma appears drunkenly touting the connections between his brother's administration and China, including plans for the Chinese to construct a new international airport outside Freetown, the capital of Sierra Leone, that will cost over $\$ 300$ million. The opposition seized upon the optics and purported message of both videos to effectively make the case for voting against the APC to the electorate. As the Sierra Leone People's Party (SLPP) put it, Sylvanus 
Koroma was “...priggishly insulting Sierra Leoneans by chanting the insinuation that the APC has sold the land to their Chinese godfathers and that there is nothing anyone can do about that." ${ }^{2}$

Both videos were significant in the highly-contested elections because they fed into an existing narrative that questioned the increasing number of Chinese commercial investments in the country with close ties to the incumbent APC government. The second video was particularly damaging to the APC's prospects of retaining the presidency because it involved the president's brother and it came just days before voters cast their ballots. ${ }^{13}$ Ultimately the APC lost the presidential elections to the SLPP following runoff elections on March 31, 2018.

As the Sierra Leone case demonstrates, regular opportunities for the contestation of elections will gradually but surely open the political space for opposition and dissent on many issues facing African electorates, including the Chinese presence in their countries. Paradoxically, Chinese investments, such as the proliferation of cheap Chinese-made cellphones in local markets, are inadvertently aiding such processes by facilitating communication that helps to increase and organize dissent.

\section{A History of Dissent}

Policymakers in China should not underestimate Africans' capacity for dissent. The continent is built on political struggles and a long history of agitation against foreign domination and intervention that should offer lessons for would-be neo-colonial aspirations. Here, historical figures and struggles that are still invoked in popular imaginations across Africa, such as the Mau Mau and Patrice Lumumba, come to mind. Beginning with Ghana and Kenyas respective movements for independence in the 1950s, a contagion effect of similar anti-colonial struggles with varying degrees of political violence took hold on the continent leading to anti-colonial wars of liberation in Guinea Bissau, Cape Verde, Angola, Zimbabwe, and Namibia, to list but a few examples. In Sudan, forces of the southern region waged a decades-long civil war beginning in 1955 against the Arab-dominated north that resulted in secession and the creation of Africa's newest state of Southern Sudan in 2011.

Every epoch in Africa's history is marked by civil society activism in which opposition groups rise to demand change and end injustice. Although aimed at domestic authoritarian regimes, the democratic wind of change and political liberalization that blew across Africa in the early 1990s further cemented Africa's reputation as a continent that resents political oppression and foreign domination. ${ }^{14}$ Thus, if the claim that China is a new neo-colonial power pervades the continent, it could be expected that a series of "anti-China protests" 
In contrast with what prevails now, the Chinese presence in African countries was less controversial during the early decades of the post-independence era because the economies of African countries had not yet hit dire straits will erupt in cities and towns across Africa. Ironically, China was once seen as an ally of anti-colonial struggles. $\mathrm{Xi}$ Jinping alluded to this fact in his address to FOCAC 2018. Several of the liberation struggles across Africa, such as Angola's struggle against the Portuguese, once received direct or tacit support from China.

In this decade, popular protests and dissent on China in Africa include mineworkers protesting their ill-treatment in Zambia and Ugandan traders protesting Chinese retail trade in Kampala in 2017. Other anti-China protests have taken place in Cameroon and the Democratic Republic of Congo in the past few years, to list some examples. Although scholars have carefully documented the popular trend in the rising tide of dissent across the continent, the full implications of these political developments are not reflected in China's current foreign policy towards investments in Africa. As Xi's speech at FOCAC 2018 shows, China is still utilizing an authoritarian-friendly, "no questions asked" foreign policy in their relations with African countries, in contradiction with the West's conditioned aid, for example, and often varying relations with African states.

In what follows, I discuss the historical background and implications of China in Africa pointing out trends that have impacted the perceptions and expectations of China's presence in Africa. Next, I discuss the structures of two significant sets of views and narratives on China in Africa. The question is whether China is unfairly exploiting Africa's resources and undermining democracy on the continent, or whether the diverse political and socio-economic relations are based on mutual benefits. The answer depends on the two competing narratives of China's presence in Africa that have emerged between incumbent politicians, their political opposition and the political elites versus the mass public. I conclude the paper with reflections on what lies ahead for the future of China-Africa relations.

\section{Coming to Africa: Part I}

Contacts between China and Africa are said to date as far back as the $9^{\text {th }}$ century predating many western European contacts with Africa. In contemporary times, China's presence in Africa has taken place in two broad phases. The first phase took place during the immediate post-independence era of the 1960s through the 1980s. The second and ongoing phase started in the aftermath of 


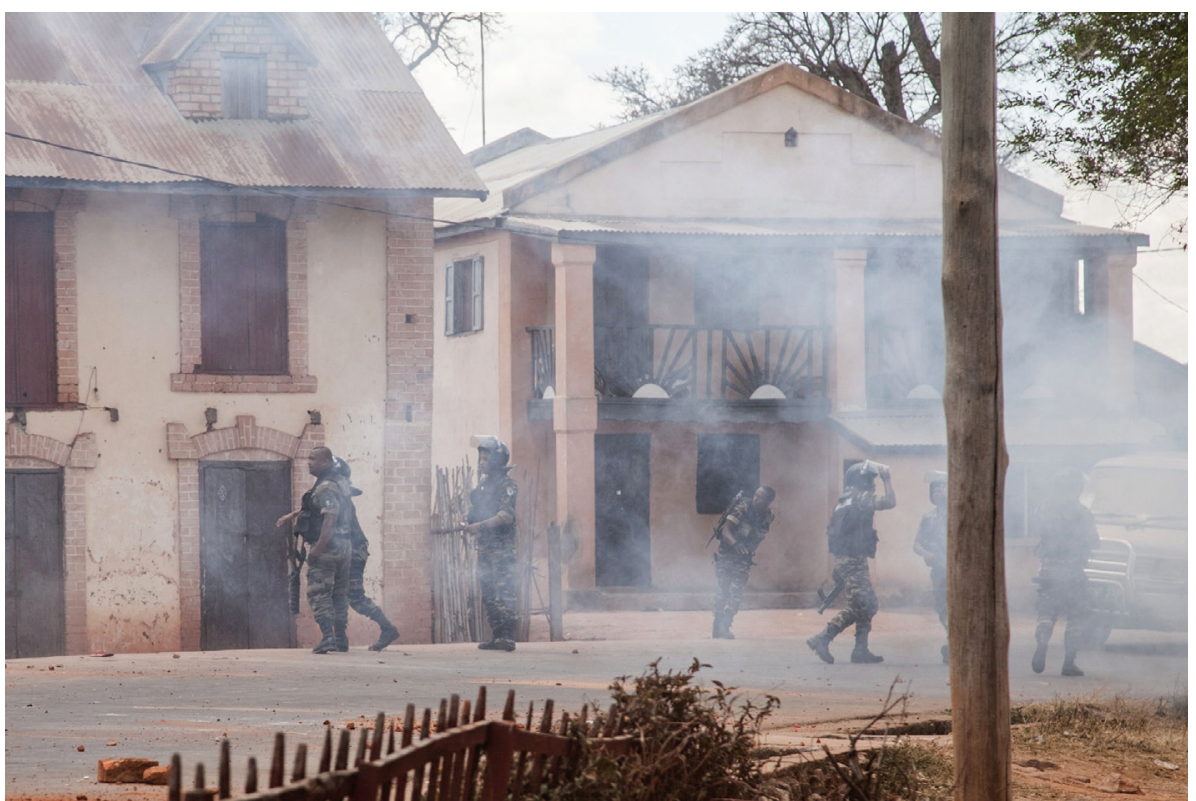

the collapse of the Soviet Union and the era of hyper-globalization that followed as internet usage proliferated across the world. The first phase of China's relations with African countries was marked by cooperative agreements between two developing societies. As Conteh-Morgan describes the relations:

...The newly formed PRC actively lent its support to African countries that were fighting wars of liberation and independence. It also gave moral ideological and material support to countries like Ghana, Guinea, and Mali that had gained independence and were trying to engage in nation-building that would be free of the shackles of neo-colonialism. This interest in the newly independent countries was in line with deliberations during the Bandung Conference where China had not only identified with the struggles of the Third World but had also expressed an interest in spearheading the goals and objectives of Third World nations. It was no surprise therefore that Chinese Premier Zhou Enlai embarked on an extensive tour of Africa between 1963 and 1964. The overall objective of the trip was to cement the friendship between China and the new African nations. This period which covers roughly the 1960s to 1976 saw the beginning of modern China-Africa relations in the areas of diplomacy, and infrastructure development, by China in Africa. ${ }^{15}$

The early phase was less problematic and relatively easier to manage for policymakers on both ends in part because the activities of the Chinese did not include the voracious quest for raw materials, as is currently the case, or competition with the Western world's foreign direct investments (FDI) in Africa. Rather, China was more focused on establishing new South-South cooperative
Police officers

fire tear gas after clashing with protestors during a demonstration on September 29, 2016 against the Chinese mining company Jiuxing, whom they accuse of forcing the rental of land and destroying property and environment, in Soamahamanina, Madagascar.

RIJASOLO / AFP / Getty Images 
and development partnerships and diplomatically isolating Taiwan. These relatively unobtrusive engagements could, of course, have been part of China's long-term strategy for engaging Africa by starting with mainly cooperative partnerships and expanding to trade agreements in subsequent decades.

In contrast with what prevails now, the Chinese presence in African countries was also less controversial during the early decades of the post-independence era because the economies of African countries had not yet hit dire straits. The debt crisis that will grip sub-Saharan Africa in the 1980s was yet to become a reality and African leaders were not desperately scouring the international community for aid, as was the case that led to heavy borrowing from the Chinese and other foreign lenders during subsequent decades.

\section{Coming to Africa: Part II}

Following the first interactions of the early post-independence era, China-Africa relations lulled for much of the 1980s as China itself faced internal problems such as the violent student uprisings and protests at Tiananmen Square in 1989. To be clear, China did not disengage completely from Africa during this time. Rather, its levels of political and socio-economic interactions with African countries plateaued compared with the 1960s and what currently prevails.

China's ongoing second foray into Africa is controversial for many reasons. Unlike previous engagements over a half century earlier, the large commercial nature of recent Chinese investments has created more opportunities for critics to claim that the deals are exploitative and disadvantageous to African countries. China's renewed focus on Africa also comes after the wind of change had blown across the continent increasing political liberalization and civil society activism aimed at addressing issues of social justice on the continent. As a result, there is now political space for dissenting voices to speak out over any aspect of China-Africa relations, or the relations between Africa and other countries, for that matter, that are considered exploitative of Africans.

\section{China in Africa: The View from Above}

Currently, Chinese investments are the authoritarian regime's best friend in Africa. Across the continent, Chinese investments are welcome alternatives to Western funds and investments for isolated regimes such as Omar al-Bashir of Sudan and Robert Mugabe of Zimbabwe who capitalize upon such investments to create some semblance of economic development to help legitimize their regimes. Although al-Bashir has faced an international arrest warrant since 2008, he has survived isolation and endured several international sanc- 
tions, including restricted travel around the world for the better part of a decade, largely with Chinese investments in Sudan's oil sector. Similarly, until he was removed from office in 2017, Robert Mugabe also survived a pariah-like status in the international community largely by relying on China's investments in Zimbabwe worth billions of dollars.

A selection of speeches delivered by African leaders at FOCAC 2018 shows that many African heads of states either paid lip service to China to solicit aid or they

From the perspectives of incumbent politicians, China's presence in Africa is welcomed. This assessment is clearly enabled by the investments, infrastructural projects, and the generous loan conditions extended by China to nearly all African governments really do not share the widespread view that China is exploiting their countries or the African continent. To list some examples, Bruno Tshibala, the Prime Minister of the Democratic Republic of the Congo said "...the Africa-China cooperation is highly complementary and mutually beneficial." According to Kassim Majaliwa, the Prime Minister of Tanzania, “...the cooperation concept and the eight major initiatives proposed by China are fully compatible with Africa's need for development... [and] ... Tanzania regards China as an important friend and partner and thanks China for its invaluable long-term support." The President of the Gambia, Adama Barrow, spoke of the China-Africa relationship and the relations between China and his country as "... China has helped us to improve our telecommunications, and road and transport conditions -things that we had wanted to do for many years but failed...facts have proved that it is a huge mistake for the Gambia to keep the so-called diplomatic relations with Taiwan [in reference to his predecessor Yahya Jammeh's decision to choose Taiwan over China]... cooperation with China will enable the Gambia to speed up its development." ${ }^{6}$

In contrast, opposition figures have seized upon China's support for authoritarian and incumbent governments to make the case to electorates that China is undermining development and exploiting their countries. Take the case of Zimbabwean opposition leader Nelson Chamisa of the Movement for Democratic Change (MDC). Like Sierra Leone in 2018, China was also a major elections issue in Zimbabwe heading into the first post-Mugabe elections. In a well-publicized speech, Chamisa told Zimbabwean voters that "China was asset-stripping the country's resources," in reference to the multibillion-dollar investments that China had made in the country under Robert Mugabe. Continuing, Chamisa pledged “...beginning September when I assume office, I will call the Chinese and tell them the deals they signed are unacceptable and they should return to their country." In addition, Chamisa promised to reorient his country's relationship with China if he won. ${ }^{17}$ 


\section{Aside from admiration for China's rapid development and some of the infrastructural projects in Africa, much of the rest of the talking points on China in Africa are negative}

as the Democratic Republic of the Congo, tend to hold the same opinion of China-Africa relations as evidenced by the speeches at the FOCAC summit. The larger point, however, is that members of the political class hold divergent views on China-Africa relations.

\section{China in Africa: The View from Below}

Although there are some internal variations, popular discourse among the mass public, civil society activists, and academic studies offer contrasting views of China-Africa relations than those held by the political classes. ${ }^{19}$ Whereas discussions of China in Africa on social media are largely negative, academic studies and surveys of the mass public offer much nuanced analyses suggesting that some segments of the African public view aspects of China in Africa positively, whereas others do not.

The findings of a 2012 study by Simon Shen and Ian Taylor ${ }^{20}$ using a sample of Ugandan youth, and the results of an Afrobarometer survey published in $2016,{ }^{21}$ are quite insightful in understanding the mass opinion of China in Africa, although they offer both contradictory and affirmative conclusions. Shen and Taylor found the Ugandan youth viewed the relationship between their country and China as relatively successful but with several negative aspects, such as a perception that Chinese workers were taking their jobs away and the Chinese exploited their natural resources. The Afrobarometer study found that 63 percent of the respondents surveyed in 36 countries believed that China has a somewhat positive influence on their country, and "a majority (56 percent) of Africans see China's development assistance as doing a 'somewhat' or 'very' good job of meeting their country's needs." Further, the study claimed, "The most important factors contributing to a positive image of China in Africa are its infrastructure/development and business investments and the cost of its products, according to survey respondents, while the quality of its products gives its image a black eye. Political and social considerations rank low among factors affecting China's image on the continent."

Advancements in mass communication technology and the proliferation of social media across Africa, ironically made possible by cheap cellphones mostly manufactured in China, is increasingly another bane of China's presence in contemporary Africa. According to some sources, there are currently over 960 
China does not have the soft power capital of the West that will help convince ordinary Africans to accept a new hegemonic influence over their economies and societies million mobile subscribers across Africa and over 216 million internet users. This unprecedented exchanging of information across the continent, primarily through Facebook, WhatsApp, YouTube but also through other social media platforms on the internet, have enabled Africans to share videos, exchange viewpoints and organize various collective actions.

There are also an increasing number of talk shows and other programs hosted by Africans on the internet at home and in the diaspora offering a wide range of analyses on African issues

that have helped shape opinion on all aspects of the contemporary relations between China and Africa from below. Among these, two are particularly noteworthy for the coverage, commentary and reactions they have provoked on what China and the Chinese are doing in Africa and the treatment of Africans in China. The two shows are Keeping It Real with Adeola, and The Dr. Mumbi Show, whose respective hosts Adeola Fayehun, a Nigerian living and broadcasting through YouTube from New York City, and Mumbi Seraki, a Kenyan who lives and broadcasts from Nairobi, Kenya, were both educated in the United States. ${ }^{22}$ Audiences on both shows frequently applaud infrastructural projects funded by China, such as the construction of the new African Union headquarters in Ethiopia, the new rail networks in Ethiopia, Kenya, and $\mathrm{Ni}$ geria, and Senegal's new airport for replacing old structures and changing the face of African countries. Others point out that airports and hotels are not pro-poor investments for ordinary Africans many of whom will never get to use such services.

Africans also admire and praise China's rapid modernization and development over the past few decades and lament that their own leaders have not been able to replicate the efforts China and the Chinese made to pull themselves up the development ladder by their own proverbial bootstraps. Aside from admiration for China's rapid development and some of the infrastructural projects in Africa, much of the rest of the talking points on China in Africa are negative. The subjects of most of the videos that are circulated include a "new racism" by China and the Chinese against Africans, the exploitation of the continent's resources by China, a new colonization of Africa by the Chinese, etc. One video even claims that China's long-term strategy is to forcefully use African countries as population outlets for resettling the excesses of China's massive population growth in future decades. Table 1 below lists a selection of the viral videos and commentary on China-Africa relations and the treatment of Africans in China that have been critical in driving discussions and shaping the viewpoints of Africans about China. 
Table 1: Select Sample of Viral Videos and Commentary on China in Africa and Africans in China

\begin{tabular}{|c|c|}
\hline Video & Implicit Message/Commentary \\
\hline $\begin{array}{l}\text { A TV commercial in China for a detergent in } 2016 \\
\text { featured a black male being washed clean and whiter and } \\
\text { reappearing at the end of the commercial as an Asian } \\
\text { male. }^{23}\end{array}$ & Racism: The Chinese are racist. \\
\hline $\begin{array}{l}\text { In } 2017 \text {, the Hubei Provincial Museum in China displayed } \\
\text { an exhibit titled "This Is Africa," which showed black } \\
\text { people side-by-side with animals. The museum eventually } \\
\text { took the exhibit down following international outcry. }{ }^{24}\end{array}$ & $\begin{array}{l}\text { Racism: The Chinese are equally racist } \\
\text { as Westerners. }\end{array}$ \\
\hline $\begin{array}{l}\text { In September 2018, a Chinese man was deported by Kenya } \\
\text { after he was captured on video by one of his employees } \\
\text { calling Kenyans "monkeys" and insulting Kenyan } \\
\text { President Uhuru Kenyatta, among other racist slurs. }{ }^{25}\end{array}$ & Racism: The Chinese are racist. \\
\hline $\begin{array}{l}\text { In 2018, a widely circulated video from Zambia shows } \\
\text { a Zambian politician standing next to a road that he } \\
\text { claimed was blocked by the Chinese with a wall inscribed } \\
\text { with Chinese letters. Zambians cannot read Chinese } \\
\text { inscriptions. }\end{array}$ & $\begin{array}{l}\text { Neo-colonialism: China is taking over } \\
\text { the economies of African countries. }\end{array}$ \\
\hline $\begin{array}{l}\text { In 2018, Kenyan parliamentarian Mutula Kilonzo Jr. } \\
\text { makes a fiery speech in parliament condemning the } \\
\text { practice of hiring Chinese workers instead of Kenyan } \\
\text { workers to work on the Standard Gauge Railway system } \\
\text { being installed in Kenya. In the widely circulated speech, } \\
\text { Kilonzo Jr. unfavorably compares Kenya to Sierra Leone, } \\
\text { saying Kenya is going to end up selling its resources for a } \\
\text { pittance to the Chinese. }\end{array}$ & $\begin{array}{l}\text { Neocolonialism: The Chinese are } \\
\text { exploiting Africa and African politicians } \\
\text { are selling out to the Chinese. }\end{array}$ \\
\hline $\begin{array}{l}\text { In September 2018, an episode of "Keeping it Real with } \\
\text { Adeola" aired featuring the FOCAC summit in Beijing. In } \\
\text { the episode, African heads of state are mocked for going to } \\
\text { "beg" in China. Adeola asks her audience what happened } \\
\text { to previous loans borrowed from China and elsewhere, } \\
\text { since the Chinese were pledging to commit another } \$ 60 \\
\text { billion towards projects in Africa. }\end{array}$ & $\begin{array}{l}\text { Exploitation: The Chinese are seeking } \\
\text { to further indebt Africa and exploit } \\
\text { them like Sri Lanka where they took } \\
\text { over a port they constructed as collateral } \\
\text { payment for none-payment of the initial } \\
\text { loan. }\end{array}$ \\
\hline $\begin{array}{l}\text { Various videos frequently circulated on the internet and } \\
\text { social media claim that the Chinese are selling plastic rice } \\
\text { in Africa; dumping unwanted or fake goods, selling engine } \\
\text { oil for cooking oil, etc. }\end{array}$ & $\begin{array}{l}\text { Exploitation: The Chinese are exploiting } \\
\text { Africa and Africans. }\end{array}$ \\
\hline $\begin{array}{l}\text { Several videos have gone viral showing Chinese mobs } \\
\text { lynching Africans in China. In one video, a black male } \\
\text { is shown bound hand and foot on the floor in a room, } \\
\text { bleeding and being mercilessly beaten with pipes by three } \\
\text { or more Chinese-looking men. }\end{array}$ & $\begin{array}{l}\text { Racism and neo-colonialism: The } \\
\text { Chinese visit and stay in Africa } \\
\text { unmolested whereas Africans are } \\
\text { mistreated in China. }\end{array}$ \\
\hline $\begin{array}{l}\text { Several videos circulate on social media showing Chinese } \\
\text { bands and artists singing African songs. }\end{array}$ & $\begin{array}{l}\text { Cultural appropriation: The Chinese are } \\
\text { stealing everything in Africa including } \\
\text { the culture of Africans. }\end{array}$ \\
\hline $\begin{array}{l}\text { The movie "Wolf Warrior 2" released in } 2017 \text { depicts a } \\
\text { Chinese special forces hero who carries out a mission in } \\
\text { Africa killing Africans and rescuing a love interest. }\end{array}$ & $\begin{array}{l}\text { A sign of things to come: Like the } \\
\text { United States and other world powers } \\
\text { have done in the past, in future China } \\
\text { will intervene by force in Africa. }\end{array}$ \\
\hline
\end{tabular}

Sources: Social media platforms, including WhatsApp, Facebook, etc. 
From the above table, racism, neo-colonialism, exploitation, and fear of the future stand out in the discussions of China among Africans at home and across the diaspora. Certainly, the image of China in Africa and how Africans perceive the Chinese have taken a serious dent over the past few years since Shen and Taylor's paper on Uganda, and the Afrobarometer study. China and the Chinese are now perceived much more negatively than positively by Africans. The perceptions are driven largely by encounters and interactions that are captured and disseminated by everyday Africans and others using technology that is ironically made possible by cheap and affordable Chinese technology.

\section{Conclusion: Beijing Is Not the "Big Apple," Yet}

To conclude, the central argument I have made in this paper is that Chinas "no questions asked" Africa policy is misguided because increased and sustained Chinese investments in Africa will help expand the size of an aspirational and educated African middle class that increasingly will express dissent on how China engages with and invests in their countries. Unless China changes its foreign policy and its investment strategy in Africa to a "questions-asked" policy that is seen as less supportive of authoritarian regimes, its engagements with African countries will ultimately be counter-productive as more Africans express dissent over their strategy. Evidence from popular and academic discourse on China in Africa and recent electoral contests provide support for the argument as African mass publics seize every political opening and space to question "bad deals" between their governments and China. Online forums that are populated and frequented by educated African middle classes and the African diaspora abound with debates and questions about China's contemporary engagements with African countries.

Some may question why the expected reciprocal relationship between foreign direct investment, development, and democracy is yet to materialize in China itself, which remains solidly authoritarian following years of development and modernization. The answer to that question lies partly in the fact that China is a self-sufficient authoritarian state without a history of democracy and without a need to respond to external motivations to abandon a one-party political system and democratize. African countries on the other hand, have long been subjected to pressures to democratize by the West in particular. This latter point is precisely why democratic governance will be the bane of China in Africa because opposition activists and pro-democracy forces, that are mostly sponsored by the West, strike a stark contrast with China's investment deals with authoritarian African regimes that oppress and immiserate their people.

Over the longer term, China's much discussed investments in Africa will prove one of two outcomes that should not be entirely unexpected. Either they will 
help to further immiserate the continent or they will help to develop it. What is evident from the start is that the investments are not currently helping change African hearts and minds in China's rivalry with the West for global influence. China does not have the soft power capital of the West that will help convince ordinary Africans to accept a new hegemonic influence over their economies and societies. Africans, for example, love soccer but China is not a global soccer powerhouse like the United Kingdom, whose soccer teams have huge followings across Africa that help create positive feelings of that country in the imaginations of young Africans. China also does not have the draw and cultural attractiveness of the West's iconic cities, such as London and New York that young migrant Africans aspire to visit. In that sense, Beijing is not yet the "Big Apple."

\section{Endnotes}

1. Greg Hiemstra and Van Der Horst, "'We Are Scared to Say No': Facing Foreign Timber Companies in Sierra Leone's Community Woodlands," Journal of Development Studies, Vol. 47, No. 4 (April 2011), pp. 574-594; Brendon Hong, "China's Ugly Exploitation of Africa and Africans," The Daily Beast, (March 6, 2018), retrieved October 3, 2018, from https://www.thedailybeast.com/chinas-ugly-exploitation-ofafricaand-africans?ref=scroll.

2. Li Xua, "Facts \& Figures: China-Africa Ties: Cooperation for a Shared Future," XinhuaNet, (September 2, 2018), retrieved October 3, 2018, from http://www.xinhuanet.com/english/2018-09/02/c_137438845. htm.

3. Seymour Martin Lipset, "Some Social Requisites of Democracy: Economic Development and Political Legitimacy," American Political Science Review, Vol. 53, No. 1 (1959), pp. 69-105; Ronald Inglehart and Christian Welzel, Modernization, Cultural Change, and Democracy, (Cambridge: Cambridge University Press, 2005).

4. Liangyu, "Full Text of Chinese President Xi Jinping's Speech at the Opening Ceremony of 2018 FOCAC Beijing Summit," XinhuaNet, (September 3, 2018), retrieved October 3, 2018, from http://www. xinhuanet.com/english/2018-09/03/c_129946189.htm.

5. Liangyu, "Full Text of Chinese President Xi Jinping's Speech."

6. "Demand for Democracy in Africa Rises, Supply Falls Short," Afrobarometer, (April 23, 2014), retrieved October 3, 2018, from http://afrobarometer.org/node/1445.

7. Byung-Kook Kim and Ezra F. Vogel (eds.), Park Chung Hee Era: The Transformation of South Korea, (Cambridge, Massachusetts: Harvard University Press, 2011).

8. Dambisa Moyo, Dead Aid: Why Aid Is Not Working and How there Is a Better Way for Africa, (New York: Farrar, Straus and Giroux, 2009).

9. Kim and Vogel (eds.), Park Chung Hee Era, pp. 1-32.

10. Abdul Rashid Thomas, "Chinese Citizens Campaigning for Ruling APC: Is Bad for Sierra Leone Democracy," The Sierra Leone Telegraph, (February 12, 2018), retrieved October 2, 2018, from https:// www.thesierraleonetelegraph.com/chinese-citizens-campaigning-for-ruling-apc-is-bad-for-sierraleone-democracy/.

11. Arran Elcoate, "'We Are Chinese': How China Is Influencing Sierra Leone's Presidential Elections," The Diplomat, (March 16, 2018), retrieved October 2, 2018, from https://thediplomat.com/2018/03/ we-are-chinese-how-china-is-influencing-sierra-leones-presidential-election/.

12. Abdulai Braima, "What-A-Man Flushed with Cash and Drunk on Arrogance," SLPP Today, (March 2, 2018), retrieved October 2, 2018, from https://www.slpptoday.com/what-a-man-flushed-with-cashand-drunk-on-arrogance/. 
13. Braima, "What-A-Man Flushed with Cash and Drunk on Arrogance."

14. Michael Bratton and Nicholas van de Walle, Democratic Experiments in Africa: Regime Transitions in Comparative Perspective, (New York: Cambridge University Press, 1997).

15. Earl Conteh-Morgan, The Sino-African Partnership: A Geopolitical Economy Approach, (New York: Peter Lang Publishing, 2018).

16. Forum on China-Africa Cooperation, retrieved October 2, 2018, from https://www.focac.org/eng/.

17. Justina Crabtree, "Zimbabwean Opposition Leader Reportedly Wants to Give Chinese Investors the Boot," CNBC, (May 3, 2018), retrieved October 2, 2018, from https://www.cnbc.com/2018/05/03/ zimbabwe-opposition-leader-wants-to-give-china-investors-the-boot.html.

18. Howard W. French, "In Africa, an Election Reveals Skepticism of Chinese Involvement," The Atlantic, (September 29, 2011), retrieved October 2, 2018, from https://www.theatlantic.com/international/ archive/2011/09/in-africa-an-election-reveals-skepticism-of-chinese-involvement/245832/.

19. Paul Tiyambe Zeleza, "The Africa-China Relationship: Challenges and Opportunities," Canadian Journal of African Studies/La Revue Canadienne des Études Africaines, Vol. 48, No. 1 (2014), pp. 145-169.

20. Simon Shen and lan Taylor, "Ugandan Youths' Perceptions of Relations with China," Asian Perspective, Vol. 36, No. 4 (October-December 2012).

21. Mogopodi Lekorwe, Anyway Chingwete, Mina Okuru, and Romaric Samson, "AD 122: China's Growing Presence in Africa Wins Largely Positive Popular Reviews," Afrobarometer, (October 24, 2016), retrieved October 2, 2018, from http://afrobarometer.org/sites/default/files/publications/Dispatches/ ab_r6_dispatchno122_perceptions_of_china_in_africa1.pdf.

22. Mumbi Seraki, "The Dr. Mumbi Show-Let's Talk Africa," retrieved October 2, 2018, from https:// drmumbishow.com/. See also, Adeola Fayehun, "Keeping It Real," retrieved October 2, 2018, from http:// www.adeolafayehun.com/.

23. "Black Man Is Washed Whiter in China's Racist Detergent Advert," The Guardian, (May 28, 2018), retrieved October 2, 2018, from https://www.theguardian.com/world/2016/may/28/china-racist-detergent-advert-outrage.

24. Russell Goldman and Adam Wu, "Chinese Museum Pulls Exhibit Comparing Animals to Black People," New York Times, (October 13, 2017), retrieved from https://www.nytimes.com/2017/10/13/world/asia/ china-racist-museum-exhibit.html.

25. Bukola Adebayo, "Chinese Man Deported from Kenya over Racist Remarks," CNN, (September 6, 2018), retrieved October 2, 2018, from https://www.cnn.com/2018/09/06/africa/kenya-deports-chinese-racist-remarks/index.html. 